\title{
Heterogeneity of the Factor IX Locus in Nine Hemophilia B Inhibitor Patients
}

\author{
R. James Matthews,“ Don S. Anson, ${ }^{\star}$ lan R. Peake, ${ }^{\star}$ and Arthur L. Bloom* \\ *Department of Hematology, University of Wales College of Medicine, Heath Park, Cardiff, Wales; and \\ ${ }^{\ddagger}$ Sir William Dunn School of Pathology, Oxford, United Kingdom
}

\begin{abstract}
DNA from nine hemophilia B patients who produce anti-factor IX inhibitors (antibodies), including two brothers, was analyzed by the Southern blotting method and hybridization with factor IX cDNA, intragenomic, and 3'-flanking probes. Two inhibitor patients were shown to have total deletions of the factor IX gene. Two other inhibitor patients, the brothers, were shown to have a presumably identical complex rearrangement of the factor IX gene involving two separate deletions. The first deletion is of $\sim 5.0 \mathrm{~kb}$ and removes exon e. The second deletion is between 9 and $29 \mathrm{~kb}$ and removes exons $g$ and $h$ but leaves exon $f$ intact. An abnormal Taq I fragment at one end of the deletion junctions acted as a marker for the inheritence of hemophilia $B$ in the patients' family. Five other inhibitor patients have a structurally intact factor IX gene as detected by this method. Our studies indicate that whereas large structural factor IX gene defects predispose hemophilia $B$ patients to developing an anti-factor IX inhibitor, the development of an inhibitor can be associated with other defects of the factor IX gene.
\end{abstract}

\section{Introduction}

Hemophilia B is an X-linked heterogeneous bleeding disorder in which normal intrinsic clotting factor IX is absent, deficient, or has been replaced by a functionally abnormal factor IX protein. The disorder affects $\sim 1$ in 30,000 newborn males in the United Kingdom. Hemophilia B patients receive replacement therapy with factor IX concentrated from pooled normal plasmas. The development of specific anti-factor IX inhibitors (antibodies) occurs in $\sim 1 \%$ of hemophilia $\mathrm{B}$ patients as a consequence of this treatment. Those patients who do not produce any immunologically recognizable factor IX protein are thought to be at most risk of developing an inhibitor to factor IX.

Cloning and sequencing of the factor IX gene (1-5) has made possible the investigation of the factor IX genes of hemophilia B patients. We have also used probes originating from flanking sequences $\sim 25,40$, and $80 \mathrm{~kb} \mathrm{3}^{\prime}$ to the factor IX gene that have been isolated by gene walking experiments (D. S. Anson and G. G. Brownlee, personal communication). Previous studies have indicated that the majority of noninhibitor patients possess no large structural alterations in the factor IX gene (6-12) although Chen (13) has reported one noninhibitor patient, Hemophilia B (Seattle 1), with a partial deletion of $10 \mathrm{~kb}$ including exons e

Address correspondence to Ian R. Peake, Department of Hematology, University of Wales College of Medicine, Heath Park, Cardiff CF4 4XN, Wales, United Kingdom.

Received for publication 23 June 1986.

J. Clin. Invest.

(c) The American Society for Clinical Investigation, Inc.

0021-9738/87/03/0746/08 \$1.00

Volume 79, March 1987, 746-753 and $\mathrm{f}$. Studies by Giannelli (6), Bernardi (8), and Hassan (14) have indicated that most inhibitor patients however, do have some kind of deletion of the factor IX gene. The first inhibitor patient we studied, Hemophilia B (Jersey 1), also had a deletion of the factor IX gene (15). We now report more information on the extent of the deletion in this patient and also results obtained with a further eight hemophilia B inhibitor patients, including two brothers.

\section{Methods}

Materials. Triton X-100, phenol, and sodium dodecyl sulfate (SDS) were obtained from BDH Chemicals Ltd., Poole, England. Salmon sperm DNA, polyvinyl-pyrrolidone, Ficoll-400, and dextran sulphate were purchased from Sigma Chemical Co., Poole, England. Agarose, low-meltingpoint agarose, and large fragment DNA polymerase I were from BRL Gibco Ltd., Paisley, Scotland.

Hybond-N membrane was purchased from Amersham International, Amersham, England. Proteinase $\mathrm{K}$ and bovine serum albumin (BSA) (fraction V) were obtained from BCL, Lewes, England. Restriction endonucleases were purchased from BCL and Anglian Biotechnology Ltd., Colchester, England. Hexadeoxyribonucleotides were from Pharmacia Ltd., Milton Keynes, England, and 32PdCTP was purchased from Du Pont (U.K.) Ltd., Stevenage, England. Kodak Ortho G X-ray film and Kodak X-Omatic cassettes were obtained from Kodak Ltd., Hemel Hempstead, England.

Patients. Peripheral blood samples were collected on nine hemophilia $B$ inhibitor patients and their family members from Hemophilia Centres in the United Kingdom, United States, France, Japan, Holland, Sweden, and Eire. We have called them Hemophilia B (Jersey 1), (15), (Boston 1), (Chicago 1), (Paris 1), (Nara 1), (Bilthoven 1), (Malmo 1), and (Dublin 1). None of the inhibitor patients showed measurable factor IX antigen in their plasma, as measured by immunoelectrophoresis and enzymelinked immunosorbent assay (16), with a sensitivity of $0.01 \mathrm{U} / \mathrm{ml}$ (i.e., $1 \%$ of normal plasma levels).

Probes. The factor IX cDNA clone used, cVII, is $\sim 2 \mathrm{~kb}$ and covers the signal peptide and mature protein coding regions and half the $3^{\prime}$ noncoding region of factor IX mRNA (Fig. 1) (4). The intragenic probes $\mathrm{XI}, \mathrm{VIII}, \mathrm{II}$, and III are located at exons a, d, e, and f respectively of the factor IX gene, and the intragenic probe IV is located midway within the intron between exons $f$ and $g$ (Fig. 1) (4). Probes Eco 3.2, Cla 1.4, and Bam 5.0 are genomic probes located at $\sim 25 \mathrm{~kb}, 40 \mathrm{~kb}$ and $80 \mathrm{~kb}$ respectively in the flanking region, $3^{\prime}$ to the end of the factor IX gene (Fig. 1). Probe pX45h is a random Xq27-linked probe that has not shown any recombination with the factor IX gene in 14 informative meioses $(17,18)$. The Xq27 probe was kindly provided by Dr. B. N. White, Kingston, Ontario, Canada.

Restriction endonuclease analysis. The patients' blood was taken into one tenth volume of $3.8 \%$ trisodium citrate and shipped in dry ice. Between 300 and $500 \mu \mathrm{g}$ of high-molecular-weight DNA was extracted from $10 \mathrm{ml}$ of blood according to the method of Kunkel (19). $10 \mu \mathrm{g}$ DNA was digested overnight with $2 \mathrm{U} / \mu \mathrm{g}$ of the appropriate restriction enzyme according to the manufacturers' conditions. The samples were electrophoresed for $1 \mathrm{~h}$ at $10 \mathrm{~V} / \mathrm{cm}$ on a Mini-Gel apparatus (Bio-Rad Laboratories Ltd., Herts, England) to check for complete digestion before loading onto a $0.7 \%$ agarose gel containing ethidium bromide $(0.5 \mu \mathrm{g} /$ $\mathrm{ml})$ and electrophoresed in a TBE buffer $(0.089 \mathrm{M}$ Tris-borate, $0.089 \mathrm{M}$ sodium citrate, $0.05 \mathrm{M}$ EDTA, $\mathrm{pH} 8.0$ ) for $20 \mathrm{~h}$ at $1.6 \mathrm{~V} / \mathrm{cm}$. Following 


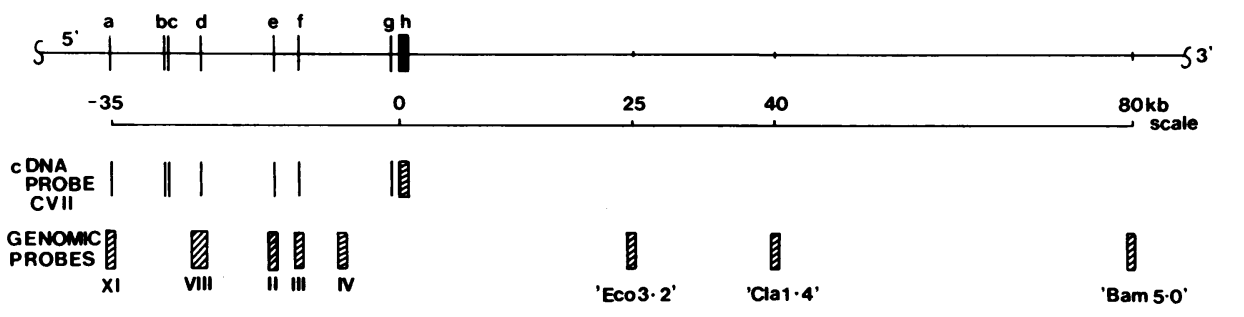

Figure 1. Factor IX gene and flanking probes. Line diagram of factor IX gene showing regions complementary to the cDNA (cVII) probe, intragenomic (XI, VIII, II, III, IV), and 3'-flanking genomic probes (Eco 3.2, Cla 1.4, Bam 5.0). electrophoresis each gel was photographed on a short-wavelength transilluminator and immediately subjected to alkali treatment $(0.5 \mathrm{M} \mathrm{NaOH}$, $1.5 \mathrm{M} \mathrm{NaCl}$ ) for $1 \mathrm{~h}$ followed by neutralization with two washes of 30 min each in $1.5 \mathrm{M} \mathrm{NaCl}, 0.5 \mathrm{M}$ Tris, pH 7.2, 0.001 M EDTA. The DNA was blot transferred from the gel to a Hybond-N membrane using the method described by Southern (20) and covalently fixed by wrapping the membrane in plastic wrap and placing the DNA surface downwards on a transilluminator for $1 \mathrm{~min}$. Prehybridization was for $1 \mathrm{~h}$ at $65^{\circ} \mathrm{C}$ in $6 \times$ standard saline citrate (SSC) $(1 \times \mathrm{SSC}$ is $0.15 \mathrm{M} \mathrm{NaCl}, 0.05 \mathrm{M}$ sodium citrate), $5 \times$ Denhardts ( $100 \times$ Denhardts is $2 \% \mathrm{wt} / \mathrm{vol} \mathrm{BSA}, 2 \%$ wt/vol PVP, 2\% wt/vol Ficoll-400), $0.5 \mathrm{SDS}, 20 \mu \mathrm{g} / \mathrm{ml}$ heat-denatured salmon sperm DNA and $10 \%$ dextran sulfate. Hybridization was for 24 $48 \mathrm{~h}$ in the same solution with the addition of a heat-denatured radioactive probe $(1.0 \mu \mathrm{Ci} / \mathrm{ml}, 5 \mathrm{ng} / \mathrm{ml})$. DNA plasmid probes were radiolabeled with 32PdCTP to $5 \times 10^{7} \mathrm{dpm} / \mu \mathrm{g}$ in a nick-translated reaction (21) or DNA plasmid inserts were radiolabeled to $5 \times 10^{8} \mathrm{dpm} / \mu \mathrm{g}$ by the oligonucleotide priming method of Feinberg and Vogelstein (22). On completion of hybridization the membranes were washed two times in 2 $\times$ SSC for $30 \mathrm{~min}$ at $65^{\circ} \mathrm{C}$ followed by two times in $2 \times \mathrm{SSC} / 0.1 \%$ (wt/ vol) SDS for $30 \mathrm{~min}$ at $65^{\circ} \mathrm{C}$ and in $0.1 \times \mathrm{SSC} / 0.1 \% \mathrm{SDS}$ for $10 \mathrm{~min}$ at $65^{\circ} \mathrm{C}$. After air drying, the membranes were exposed to Kodak Ortho$\mathrm{G}$ film at $-70^{\circ} \mathrm{C}$ for $2-10 \mathrm{~d}$. For rehybridization the membranes were first incubated in $0.4 \mathrm{M} \mathrm{NaOH}$ at $45^{\circ} \mathrm{C}$ for $30 \mathrm{~min}$ followed by incubation in $0.1 \times \mathrm{SSC} / 0.1 \% \mathrm{SDS} / 0.2 \mathrm{M}$ Tris, $\mathrm{pH} 7.5$, at $45^{\circ} \mathrm{C}$ for $30 \mathrm{~min}$ before repeating the prehybridization protocol.

\section{Results}

An analysis of large structural alterations such as deletions and insertions in the factor IX genes of hemophilia B patients is simplified by the X-chromosome linkage of the factor IX gene whereby males possess only a single copy of the gene.

Fig. 2 shows the results of three hemophilia B inhibitor patient DNA samples, Hemophilia B (Bilthoven 1), (Malmo 1), and (Nara 1), (tracks 1-3 respectively) and one normal male DNA (track 4), cut with the restriction enzyme TaqI and probed with the cDNA (cVII) probe. Six fragments containing the different exons of the factor IX gene were visible in each of the tracks. TaqI is a particularly useful restriction enzyme in this context because it resolves most of the exons of the factor IX gene (Fig. 3). Exon a is not detectable because of the inefficient binding to the filter of the 300-bp TaqI fragment that contains exon a. Note that exon $\mathrm{d}$ can be found in either a 1.8-kb fragment or a 1.3-kb fragment due to the polymorphic TaqI site $3^{\prime}$ to exon $\mathrm{d}$ (23). Each of these patients was normal for all of the fragments generated by TaqI and the cDNA probe suggesting that their factor IX genes were essentially intact although we would not have detected small insertions or deletions. To check for the overall integrity of exon a and 5 ' promoter sequences in these

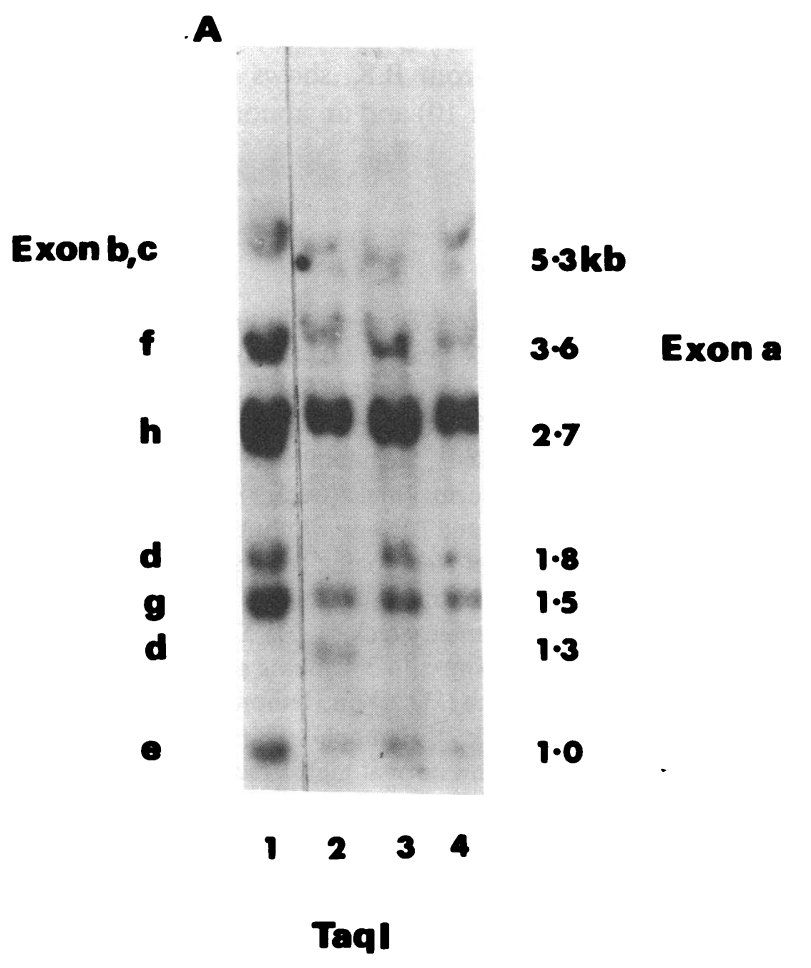

B

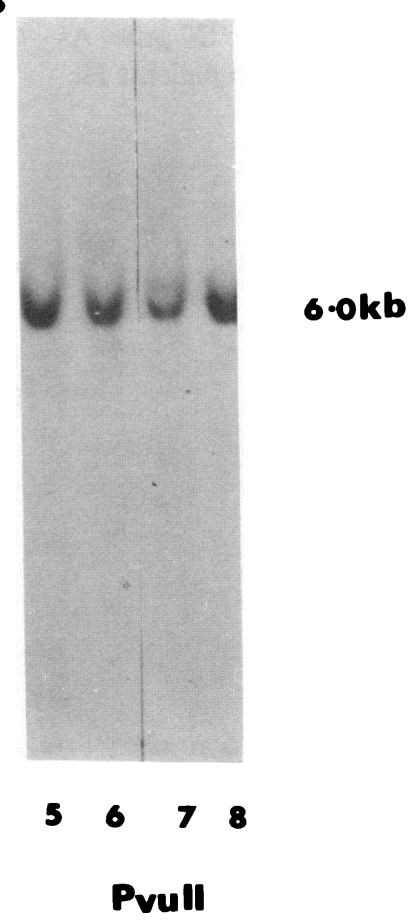

Figure 2. Southern blotting analysis of factor IX genes in three hemophilia B inhibitor patients. Result of (A) TaqI digestion and probing with the cDNA (cVII) probe on Hemophilia B (Bilthoven 1) (track 1), Hemophilia B (Malmo 1) (track 2), Hemophilia B (Nara 1) (track 3), and normal male (track 4) (note that exon $\mathrm{d}$ can be found as a $1.8-\mathrm{kb}$ or 1.3-kb fragment due to the polymorphic TaqI site $3^{\prime}$ to exon d, see Fig. 3), (B) Pvull digestion and probing with intragenomic probe $\mathrm{XI}$ (containing exon a) on Hemophilia B (Bilthoven 1) (track 5), Hemophilia B (Malmo 1) (track 6), Hemophilia B (Nara 1) (track 7), and normal male (track 8). 


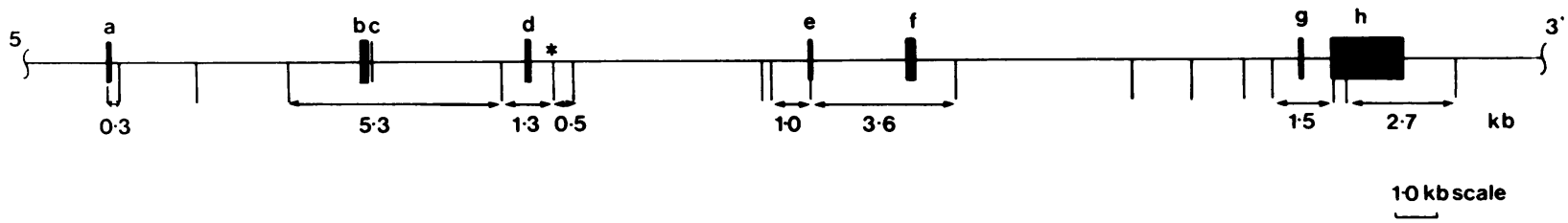

Figure 3. TaqI restriction enzyme map of the factor IX gene. Line diagram of the factor IX gene showing location of exons a-h (solid bars) and TaqI restriction enzyme sites. Lengths of TaqI fragments containing exons are indicated in $\mathbf{k b}$.

inhibitor patients, DNA samples from all three together with a normal male DNA were digested with PvuII and probed with intragenomic probe XI, which includes exon a (Fig. 1). A normal fragment of $6.0 \mathrm{~kb}$ was generated in each of the patient and control DNAs (tracks 5-8, Fig. 2). Identical results using the cDNA probe and intragenomic probe XI were obtained with one other inhibitor patient, Hemophilia B (Dublin 1) (results not shown). One further inhibitor patient, Hemophilia B (Paris 1), was also shown to have a grossly intact factor IX gene, but with a point mutation in exon $\mathrm{h}$ (manuscript in preparation).

The results obtained with DNA samples from inhibitor patients Hemophilia B (Jersey 1) and (Boston 1) and a normal male when digested with TaqI and probed with the CDNA probe are shown in Fig. 4 (tracks 1, 2, 3 respectively). Hemophilia B (Jersey 1) and (Boston 1) do not possess the fragments corresponding to exons $b-h$. Likewise they are lacking exon a due to the absence of hybridization band $6.0 \mathrm{~kb}$ when probed with intragenomic probe XI after PvuII digestion (tracks 4 and 5). To further investigate the extent of the deletion in these two patients, their DNA was probed with $3^{\prime}$ flanking probes at $\sim 25$ $\mathrm{kb}, 40 \mathrm{~kb}$, and $80 \mathrm{~kb}, 3^{\prime}$ to exon $\mathrm{h}$ of the factor IX gene. Hemophilia B (Jersey 1) gave no hybridization bands with any of the 3 -flanking probes (tracks $7,10,13$ ), indicating that in this condition the deletion is a minimum length of $114 \mathrm{~kb}$ including the whole of the factor IX gene. Similar results were obtained with Hemophilia B (Boston 1), (tracks 8 and 11; the result with the $80-\mathrm{kb}$ probe is not shown), also indicating a minimum deletion of $114 \mathrm{~kb}$, including the whole of the factor IX gene. As positive control tracks 15 and 16 reveal that both patients He- mophilia B (Jersey 1) and (Boston 1) possess the correct TaqI hybridization band of $4.5 \mathrm{~kb}$ with the probe $\mathrm{pX} 45 \mathrm{~h}$, a random Xq27 region probe (see Methods). Tracks 6, 9, 12, 14, and 17 in Fig. 4 contain normal male DNA. An autoradiograph of a Southern blot of genomic DNA from patient B.K., Hemophilia B (Chicago 1), cut with TaqI and probed with the cDNA probe (cVII), is shown in Fig. 5 (track 2). Patient B.K. is missing the $1.0,3.6,1.5$, and $2.7-\mathrm{kb}$ fragments corresponding to exons $\mathrm{e}, \mathrm{f}$, $\mathrm{g}$, and $\mathrm{h}$, but retains the 5.3 and $1.8-\mathrm{kb}$ fragments corresponding to exons $\mathrm{b} / \mathrm{c}$ and $\mathrm{d}$ respectively. In addition he has an abnormal fragment of $4.5 \mathrm{~kb}$. DNA from his brother P.K. showed the same pattern of fragments (results not shown). Presumably these brothers have inherited the same defective factor IX gene and hence have identical rearrangements of the gene.

To investigate this rearrangement in more detail, DNA from B.K. was digested independently with restriction enzymes BglII, Pvull, and TaqI and was probed with intragenic probes located between exons $\mathrm{c}$ and $\mathrm{g}$ (see Table $\mathrm{I}$ and Fig. 5). Fig. 5, track 3 contains DNA from a normal male and shows the normal 4.4 and $8.0-\mathrm{kb}$ fragments generated after PvulI digestion and probing with probe VIII (includes exon d, Figs. 1 and 6). B.K. however shows the normal 4.4-kb fragment together with an abnormal 3.0-kb fragment (Fig. 5, track 4). Fig. 5, track 5 shows the normal 3.6 and 1.0-kb TaqI fragments in DNA from a normal male probed with probe II (includes exon e, Figs. 1 and 6). No autoradiographic signal was observed in DNA from B.K. with this probe, (Fig. 5, track 6), implying that this part of the gene is deleted. In contrast DNA from B.K. shows a normal 1.0-kb PvulI fragment (Fig. 5, track 10) and an abnormal 4.5-kb TaqI
A

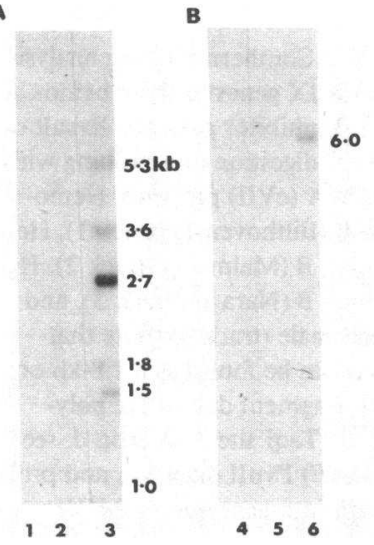

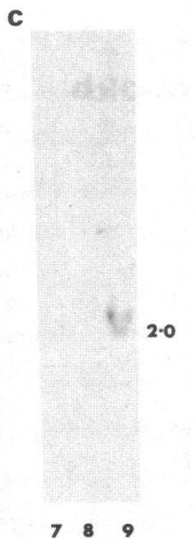

E

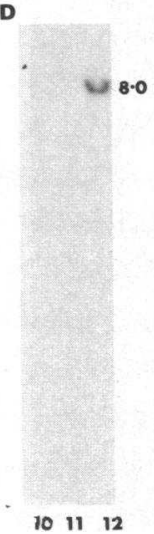

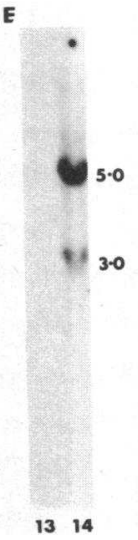

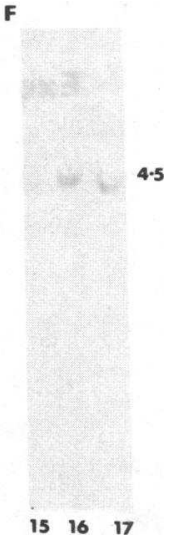

Figure 4. Southern blotting analysis of factor IX locus in two hemophilia B inhibitor patients. Result of $(A)$ TaqI digestion and cDNA probing of Hemophilia B (Jersey 1) (track 1), Hemophilia B (Boston 1) (track 2), normal male (track 3), (B) Pvull digestion and probing with intragenomic probe XI on Hemophilia B (Jersey 1) (track 4), Hemophilia B (Boston 1) (track 5) and normal male (track 6), (C) TaqI digestion and probing with $3^{\prime}$ flanking genomic probe Eco $3.2 \mathrm{~kb}$ (Fig. 1) on Hemophilia B (Jersey 1) (track 7), Hemophilia B (Boston 1) (track 8), and normal male (track 9), (D) TaqI digestion and probing with 3 '-flanking geno-

mic probe Cla 1.4 kb (Fig. 1) on Hemophilia B (Jersey 1) (track 10), Hemophilia B (Boston 1) (track 11), and normal male (track 12), (E) TaqI digestion and probing with $3^{\prime}$ flanking probe Bam $5.0 \mathrm{~kb}$ (Fig. 1) on Hemophilia B (Jersey 1) (track 13), and normal male (track 14), (F) TaqI digestion and probing with pX45h $(15,16)$ on Hemophilia B (Jersey 1) (track 15), Hemophilia B (Boston 1) (track 16), and normal male (track 17). 


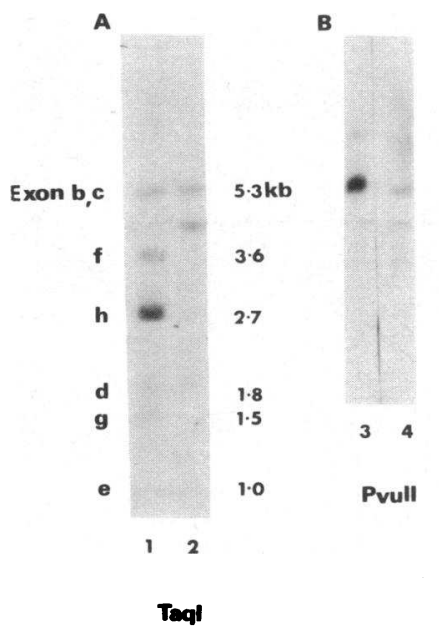

fragment (Fig. 5, track 8) after probing with probe III (includes exon f, Figs. 1 and 6). This result suggests the retention of exon $f$ in the B.K. factor IX gene. No signal was observed with DNA from B.K. with probe IV (Figs. 1 and 6), (Fig. 5, track 12). Normal fragments were observed with probe XI and flanking probes at 20,40 , and $80 \mathrm{~kb} 3^{\prime}$ to the factor IX gene with B.K. DNA (results not shown).

These results indicate that there are four breakpoints within the factor IX locus in Hemophilia B (Chicago 1). Breakpoint A must be located within the intron separating exons $d$ and $e$ and breakpoint $B$ in the intron separating exons $e$ and $f$, thus creating deletion 1 of $\sim 5.0 \mathrm{~kb}$ including exon e (see Fig. 6). Breakpoint $\mathrm{C}$ must be located within the $3 \mathrm{~kb}$ immediately $3^{\prime}$ to exon $\mathrm{f}$ (Fig. 6). Breakpoint D must be situated in the $20 \mathrm{~kb}$ that separates exon $h$ and the locus for the Eco $3.23^{\prime}$ flanking probe (Fig. 1). Breakpoints $C$ and $D$ have generated deletion 2 of between 9 and $29 \mathrm{~kb}$ that includes exons $\mathrm{g}$ and $\mathrm{h}$.

Table I. Size of Restriction Enzyme Fragments in Hemophilia B (Chicago 1)

\begin{tabular}{|c|c|c|c|}
\hline $\begin{array}{l}\text { Intra-genomic } \\
\text { probe }\end{array}$ & & Size in normal & $\begin{array}{l}\text { Size in patients } \\
\text { B.K., P.K. }\end{array}$ \\
\hline & & $k b$ & $k b$ \\
\hline & Bgl II & $7.5,4.6,0.5$ & $11.0,4.6,0.5$ \\
\hline \multirow[t]{3}{*}{ VIII } & Pvu II & $8.0,4.4$ & $3.0,4.4$ \\
\hline & Taq I & $5.3,1.8 / 1.3$ & $5.3,1.8$ \\
\hline & Bgl II & 12.0 & \\
\hline \multirow[t]{3}{*}{ II } & Pvu II & 8.0 & No signal \\
\hline & Taq I & $3.6,1.0$ & \\
\hline & Bgl II & 12.0 & 11.0 \\
\hline \multirow[t]{3}{*}{ III } & Pvu II & 1.0 & 1.0 \\
\hline & Taq I & 3.6 & 4.5 \\
\hline & Bgl II & 12.0 & \\
\hline \multirow[t]{2}{*}{ IV } & Pvu II & 3.8 & No signal \\
\hline & Taq I & 4.6 & \\
\hline
\end{tabular}

Figure 5. Southern blot analysis of the factor IX gene in hemophilia B inhibitor patient B.K. with Hemophilia B (Chicago 1). Result of $(A)$ TaqI digestion and probing with $\mathrm{cDNA}$ probe (cVII) on normal male (track 1) and Hemophilia B (Chicago 1) (track 2), (B) Pvull digestion and probing with intragenomic probe VIII on normal male (track 3 ) and Hemophilia B (Chicago 1) (track 4). (C) TaqI digestion and probing with intragenomic probe II on normal male (track 5) and Hemophilia B (Chicago 1) (track 6). (D) TaqI and Pvull digestions and probing with intragenomic probe III on normal male (tracks 7 and 9 respectively) and Hemophilia B (Chicago 1) (tracks 8 and 10 respectively). (E) TaqI digestion and probing with intragenomic probe IV on normal male (track 11) and Hemophilia B (Chicago 1) (track 12).
We have also performed a study using TaqI and probe III on this Hemophilia B (Chicago 1) family (Fig. 7). The patients' grandmother, M.K. (track 4), is homozygous for the normal 3.6$\mathrm{kb}$ fragment, whereas the patients' mother (R.K.) and sister (T.K.), (tracks 2 and 3 respectively) possess the $3.6-\mathrm{kb}$ fragment and the abnormal $4.5-\mathrm{kb}$ fragment. Since the patients' grandfather did not have hemophilia B the mutation must have arisen at the level of the patients' mother. An abnormal 11-kb fragment seen after BglII digestion with probes VIII and/or III (Table I and Fig. 6) in B.K. and P.K. and their mother R.K. is a marker for the presence of both deletions (results not shown). Interestingly, since grandmother M.K. only shows the normal $12-\mathrm{kb}$ BglII fragment with probe III, then both deletions appear to have arisen at the same time.

In addition DNA from 25 noninhibitor hemophilia B patients was digested independently with 15 different restriction enzymes and probed with the cDNA probe. In each case all the hybridization fragments were found to be normal (results not shown).

\section{Discussion}

Of the nine hemophilia B inhibitor patients studied, including two brothers, five appear to have intact factor IX genes. We presume that gene mutations such as single nucleotide changes or small deletions rarely detected by this kind of analysis are responsible for the defect in these patients. A single nucleotide substitution affecting the correct maturation of factor IX mRNA has already been described in one case of severe hemophilia B (24). Fig. 8 illustrates the extent of the deletions in Hemophilia B (Jersey 1), (Boston 1), and (Chicago 1) compared to factor IX deletions already reported $(6,8,13,14)$.

The deletions in Hemophilia B (Jersey 1) and (Boston 1) are of a minimum size of $114 \mathrm{~kb}$, but the $5^{\prime}$ and $3^{\prime}$ breakpoints have yet to be characterized. The factor IX gene has been located to the Xq27 region of the X-chromosome (25-28). Since Hemophilia B (Jersey 1) and (Boston 1) show a positive result with pX45h, also located in the Xq27 region $(17,18)$, at least one of the deletion breakpoints in these conditions must be situated within this region. Karyotype analysis in Hemophilia B (Jersey 


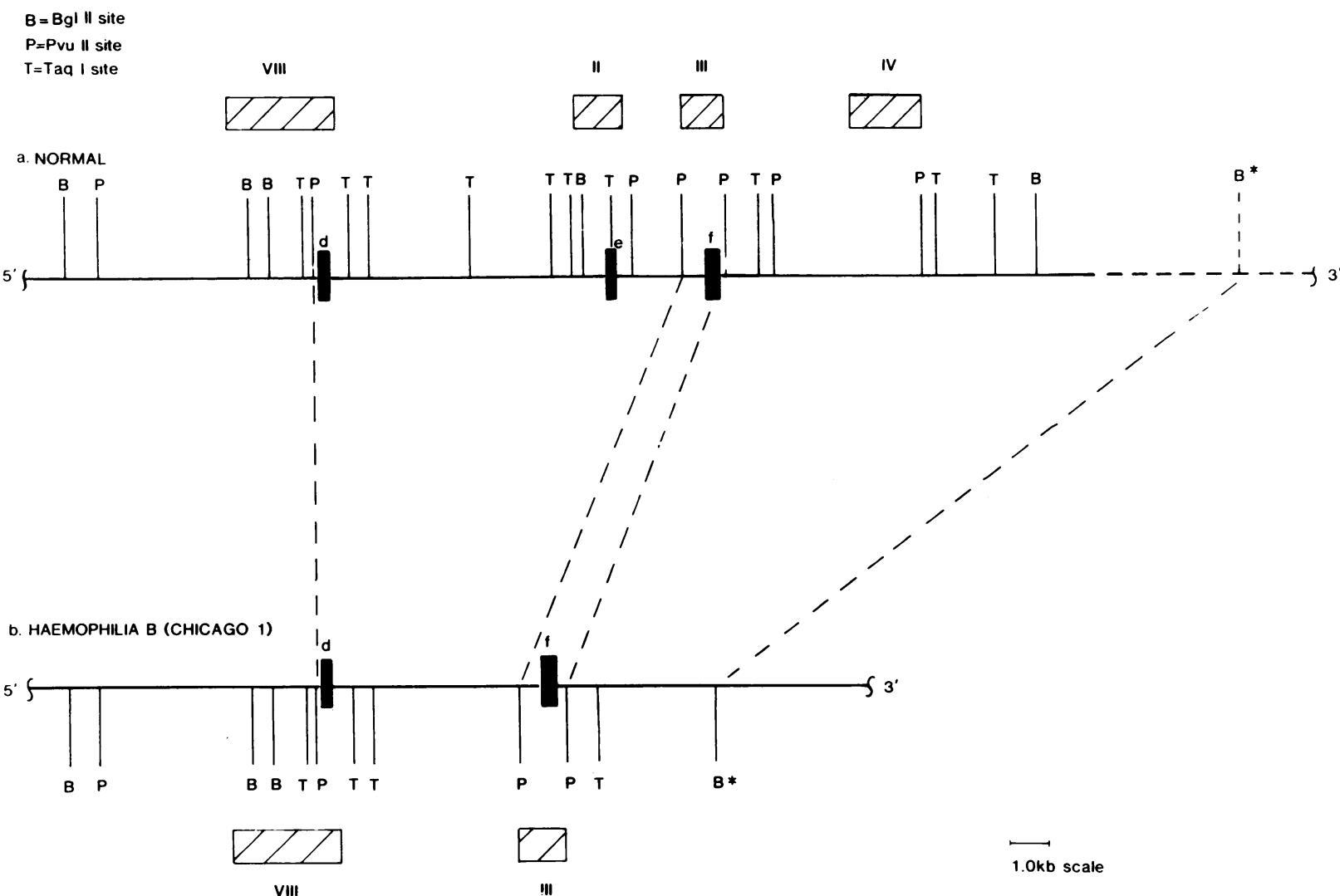

Figure 6. Restriction map showing the positions of deletions in Hemophilia B (Chicago 1). (a) Map of the central $26 \mathrm{~kb}$ of the normal factor IX gene (from references 4 and 5) showing exons d, e, and $\mathrm{f}$ (solid bars), restriction sites for BglII $(B)$, PvulI $(P)$, and TaqI $(T)$ and the

1) showed no abnormalities. Three other patients, Hemophilia B (Manchester 1), (Manchester 2) (Giannelli et al. patients 1 and 2, reference 6) and Hemophilia B (Pisa 1) (8), also have complete deletions of the factor IX gene with undefined breakpoints (Fig. 8).

location of intragenomic probes VIII, II, III, and IV (hatched boxes) (b) Map of the factor IX gene in Hemophilia B (Chicago 1) showing the location of deletion 1 (between exons $d$ and $f$ ) and deletion 2 ( $3^{\prime}$ to exon f).

Hemophilia B (Chicago 1) is a complex rearrangement of the factor IX gene that appears to involve two discrete deletions, one of $\sim 5.0 \mathrm{~kb}$ and the other of between 9 and $29 \mathrm{~kb}$. At present we have no idea of the mechanism that could cause such a rearrangement but we are in the process of cloning a DNA

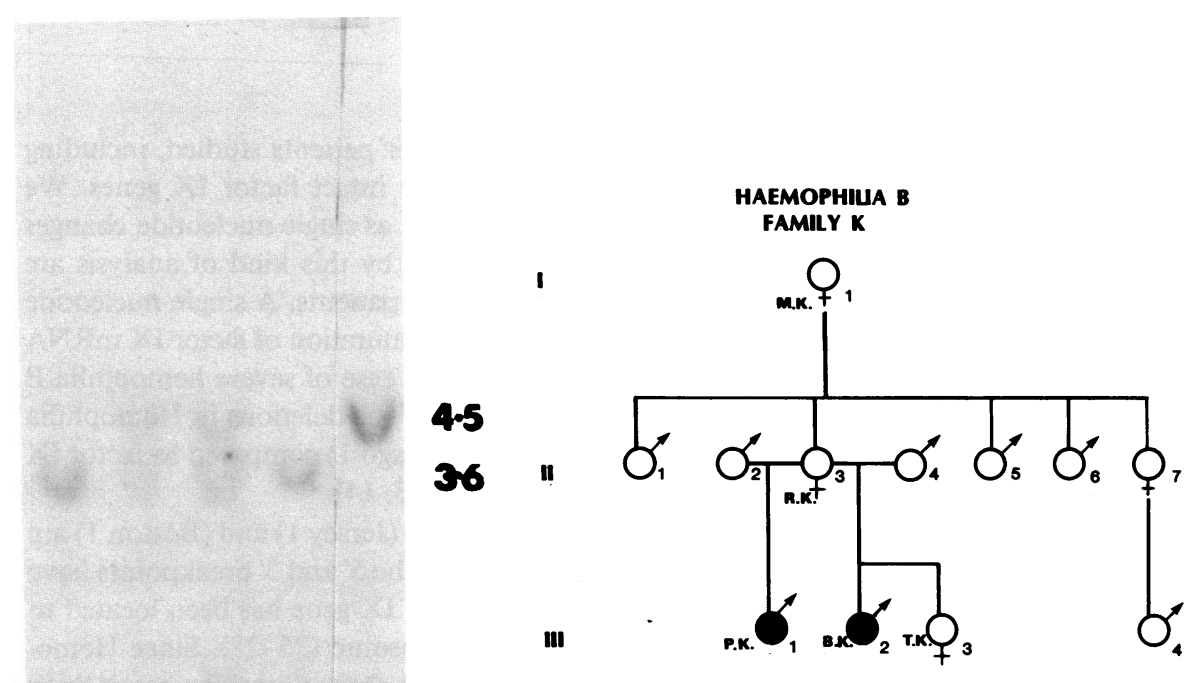

N TK RK MK PK
Figure 7. Pedigree of family K (Hemophilia B [Chicago 1]) and Southern blotting analysis using intragenomic probe III to detect the inheritance of the abnormal TaqI fragment in this family. DNA from proband P.K. (III-1), patients' sister T.K. (III-3), patients' mother R.K. (II-3), and patients' grandmother M.K. (I-1) restricted with TaqI and probed with probe III. 

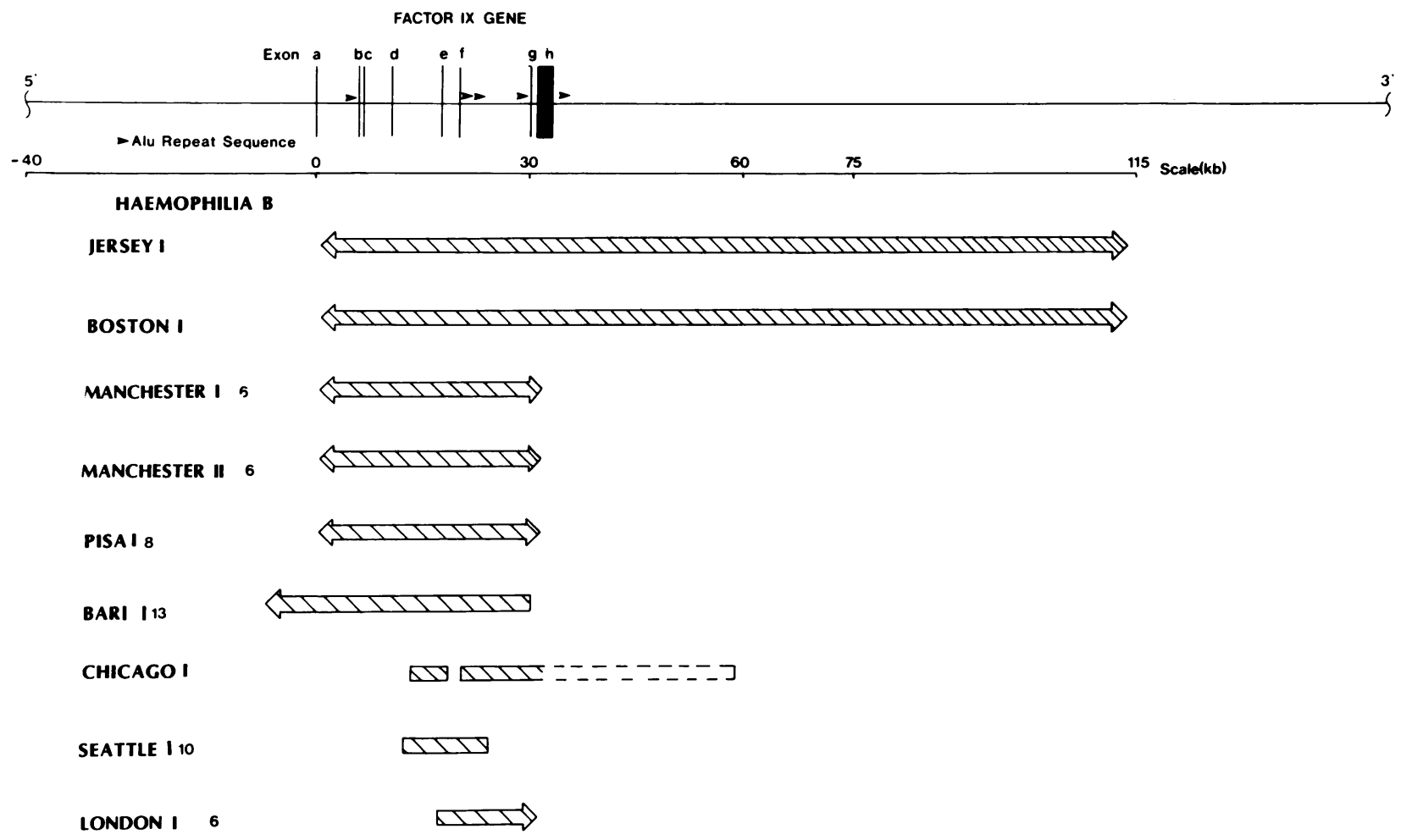

Figure 8. Summary of deletions found in the factor IX genes of Hemophilia B patients. Extent of the deletion in Hemophilia B (Jersey 1), Hemophilia B (Chicago 1), and Hemophilia B (Boston 1) compared with factor IX gene deletions already reported $(6,8,13,14)$. Arrows indicate that the endpoints of a deletion have not been determined. Hatched and open areas show the extent and approximate end of a deletion respectively.

fragment from patient B.K. that spans both deletion junctions to characterize the sequences at the breakpoints. Jones et al. (29) have reported a rearrangement of the human $\beta$-globin gene cluster involving an inversion of the sequences between the $\mathrm{A} \gamma$ and $\delta$-globin genes that was flanked by two deletions. We believe that Hemophilia B (Chicago 1) is the first observation of a natural gene rearrangement involving two separate deletions within the same gene.

Hemophilia B (Chicago 1) involves the removal of exon e, encoding amino acids 85-127, and exons $g$ and $h$ encoding amino acids $196-415$. The polyadenylation/cleavage signal of the factor IX mRNA are also deleted. The two affected brothers do not appear to synthesize any factor IX antigen, possibly as a result of incorrectly $3^{\prime}$ processed and unstable factor IX mRNA. In contrast, Hemophilia B (Seattle 1) (13) is a deletion where exons $e$ and $f$ are removed and the patients synthesize low levels of a partial factor IX antigen but have not developed an antifactor IX inhibitor (30). In this condition all the correct signals for $3^{\prime}$ processing of the factor IX mRNA are presumed to be intact allowing a truncated factor IX protein to be translated.

It is interesting to note that the $5^{\prime}$ breakpoints in Hemophilia B (Chicago 1) (deletion 2) and (London 1), (a partial deletion reported by Giannelli et al., reference 6), and the $3^{\prime}$ breakpoints in Hemophilia B (Chicago 1) (deletion 1), (Seattle 1) (13), and (Bari 1) (14), are located near Alu repeat sequences. Four highly repetitive AluI sequences are present in the factor IX gene (5). The first is in the intron between exons a and $b$, and the next three are within the intron between exons $f$ and $g$. A fifth is found in the flanking region of the $3^{\prime}$ end of the gene. Reports that some $\beta$-globin gene cluster $(31,32)$ and low-density lipoprotein receptor gene (33) deletions have breakpoints close to or within family repeat sequences possibly indicates the existence of a general mechanism that can result in large gene deletions. It is hoped that by cloning and sequencing the deletion junction regions of Hemophilia $B$ (Chicago 1) the proximity of the repeat sequences will be better assessed.

Giannelli et al. $(6,34)$ have proposed that the origin of antibodies to factor IX in hemophilia B patients is due to their lack of immune tolerance to epitopes in the factor IX protein. This can either be due to lack of expression of any factor IX antigen, or to synthesis of an altered factor IX molecule lacking certain epitopes that are critical for the initial development of tolerance. Whereas all nine hemophila B patients we have studied appear to satisfy these criteria in having undetectable plasma factor IX, in only four is this absence due to a large deletion of the factor IX gene. In addition several of the noninhibitor patients we have studied do not produce any measurable factor IX antigen in plasma. However it is possible that these patients synthesize small amounts of factor IX that, although undetectable by our assays, are sufficient to allow induction of immune tolerance. Alternatively these patients may have lost the ability to synthesize factor IX after the development of tolerance. Secondary factors such as the treatment regime and/or polymorphism of the immune response could also be influential in predisposing only a percentage of hemophilia B patients to develop an inhibitor (35). Evidence for this comes from family studies where only one of two affected individuals has developed an inhibitor (35).

Of the 14 hemophilia B inhibitor patients thus far reported, eight have a detectable deletion of the factor IX gene $(6,8,14$, 15 , and this study), whereas in only 2 of 19 hemophilia $A$ inhibitor patients studied is inhibitor development associated with a detected gene deletion (36-38). As the overall incidence of 
gene deletions in hemophilia $A$ and $B$ is approximately the same (1-2\%) $(6-14,36-38)$, single nucleotide changes or small insertions/deletions in the factor VIII gene appear to result in the development of inhibitors in hemophilia A more frequently than similar kinds of changes in the factor IX gene in hemophilia B. This is presumably due to loss of the epitopes critical to the development of immune tolerance as discussed above. Additionally the much lower plasma level of factor VIII compared with factor IX ( $100 \mathrm{ng} / \mathrm{ml}$ compared with $10 \mu \mathrm{g} / \mathrm{ml})$ may be significant in the establishing of self-immune tolerance to these proteins in hemophilia A and B patients with lowered levels of factor VIII and factor IX respectively.

\section{Acknowledgments}

We thank the following for supplying us with blood samples and allowing us to study their patients: Dr. E. Czapek, Chicago, IL, (Hemophilia B [Chicago 1]), Dr. Y. Sultan, Paris, France (Hemophilia B [Paris 1]), Prof. I. Temperley, Dublin, Eire (Hemophilia B [Dublin 1]), Dr. E. J. M. Sjamsoedin-Visser, Bilthoven, Netherlands (Hemophilia B [Bilthoven 1]), Prof. I. M. Nilsson, Malmo, Sweden (Hemophilia B [Malmo 1]), Dr. A. Yoshioka, Nara, Japan (Hemophilia B [Nara 1]), and Dr. A. Forsberg, Worcester, MA (Hemophilia B [Boston 1]). We are indebted to Dr. B. A. White, Queen's University, Kingston, Ontario, for supplying us with probe $\mathrm{pX} 45 \mathrm{~h}$.

This work was supported by a grant to Dr. Peake from the Arthritis and Rheumatism Council and a Medical Research Council grant G8405633CB to Dr. Anson.

\section{References}

1. Choo, K. H., K. G. Gould, D. J. G. Rees, and G. G. Brownlee. 1982. Molecular cloning of the gene for antihemophilic factor IX. Nature (Lond.). 299:178-190.

2. Kurachi, K., and E. W. Davie. 1982. Isolation and characterization of a cDNA coding for human factor IX. Proc. Natl. Acad. Sci. USA. 79: 6461-6464.

3. Jaye, M., H. de la Salle, F. Schamber, A. Balland, V. Kohli, A. Findeli, P. Tolstoshev, and J.-P. Lecocq. 1983. Isolation of a human antihemophilic factor IX cDNA using a unique 52 base synthetic oligonucleotide probe deduced from the amino-acid sequence of bovine factor IX. Nucl. Acids Res. 11:2325-2335.

4. Anson, D. S., K. H. Choo, D. J. G. Rees, F. Giannelli, K. Gould, J. A. Huddleston, and G. G. Brownlee. 1984. The gene structure of antihemophilic factor IX. EMBO (Eur. Mol. Biol. Organ.) J. 3:10531060.

5. Yoshitake, S., B. Schach, D. C. Foster, E. W. Davie, and K. Kurachi. 1985. Nucleotide sequence of the human factor IX (antihemophilic factor B). Biochemistry. 24:3736-3750.

6. Giannelli, F., K. H. Choo, D. J. G. Rees, Y. Boyd, C. R. Rizza, and G. G. Brownlee. 1983. Gene deletions in patients with hemophilia $B$ and anti-factor IX antibodies. Nature (Lond.). 303:181-182.

7. Hassan, H. J., M. Orlando, A. Leonardi, C. Chelucci, R. Guerriero, P. M. Mannucci, G. Mariani, and C. Peschle. 1985. Intragenic factor IX restriction site polymorphism in hemophilia B variants. Blood. 65: 441-443.

8. Bernardi, F., L. Del Senno, R. Barbieri, D. Buzzoni, R. Gambari, G. Marchetti, F. Conconi, F. Panicucci, M. Positano, and S. Pitruzzello. 1985. Gene deletion in an Italian hemophilia B subject. J. Med. Genet. 22:305-307.

9. Matthews, R. J., M. B. Liddell, D. P. Lillicrap, and I. R. Peake. 1985. Gene analysis in hemophilia B. Thromb. Haemostasis. 54:910. (Abstr.)

10. Chen, S-H., K. Kurachi, S. Yoshitake, P. F. Chance, G. L. Bray, A. R. Thompson, and C. R. Scott. 1985. Point mutation and intra-genic deletion of factor IX gene as a cause of hemophilia B. Am. J. Hum. Genet. 37:015. (Abstr.)

11. Driscoll, M. C., C. H. Miller, M. W. Hildgartner, and L. M. Aledort. 1985. Gene analysis and DNA polymorphisms in hemophilia B. Blood. 66:1217. (Abstr.)

12. Poon M-C., D. I. Hoar, and D. Chui. 1986. Identification of factor IX variants and hemophilia B carriers using cloned DNA probes. Clin. Res. 34:662A. (Abstr.)

13. Chen, S-H., S. Yoshitake, P. F. Chance, G. L. Bray, A. R. Thompson, C. R. Scott, and K. Kurachi. 1985. An intra-genic deletion of the factor IX gene in a family with hemophilia B. J. Clin. Invest. 76: 2161-2164.

14. Hassan, H. J., A. Leonardi, R. Guerriero, C. Chelucci, L. Cianetti, N. Ciavarella, P. Ranieri, D. Pilolli, and C. Peschle. 1985. Hemophilia $B$ with inhibitor: molecular analysis of the sub-total deletion of the factor IX gene. Blood. 66:728-730.

15. Peake, I. R., B. L. Furlong, and A. L. Bloom. 1984. Carrier detection by direct gene analysis in a family with hemophilia B (factor IX deficiency). Lancet. i:242-243.

16. Yoshioka, A., J. C. Giddings, J. E. Thomas, Y. Fujimura, and A. L. Bloom. 1985. Immunoassay of factor IX antigen using monoclonal antibodies. Brit. J. Haematol. 59:265-275.

17. Holden, J. J. H., L. M. Mulligan, C. Forster-Smith, N. E. Simpson, B. N. White, I. Oberle, and K. Wrogemann. 1985. Application of flanking DNA probes to carrier detection in the fragile-X syndrome. In Human Gene Mapping 8. Eighth International Workshop on Human Gene Mapping. A. de la Chapelle, editor. S. Karger AG, Basel, Switzerland. 653.

18. Mulligan, L. M., M. A. Phillips, C. J. Forster-Gibson, J. Beckett, M. W. Partington, N. E. Simpson, J. J. A. Holden, and B. N. White. 1985. Genetic mapping of DNA segments relative to the fragile-X syndrome at Xq27.3. Am. J. Hum. Genet. 37:463-472.

19. Kunkel, L. M., K. D. Smith, S. H. Boyer, D. S. Borgaonkar, S. S. Wachtel, O. J. Miller, W. R. Breg, H. W. Jones, and J. M. Rary. 1977. Analysis of human Y-chromosome specific reiterated DNA in chromosome variants. Proc. Natl. Acad. Sci. USA. 74:1245-1249.

20. Southern, E. M. 1975. Detection of specific sequences among DNA fragments separated by gel electrophoresis. J. Mol. Biol. 98:503518.

21. Rigby, P. W. J., M. Dieckmann, C. Rhodes, and P. Berg. 1977. Labelling DNA to high specific activity in-vitro by nick translation with DNA polymerase I. J. Mol. Biol. 113:237-251.

22. Feinberg, A. P., and B. Vogelstein. 1983. Technique for radiolabelling DNA restriction endonuclease fragments to high specific activity. Anal. Biochem. 132:6-13.

23. Giannelli, F., K. H. Choo, P. R. Winship, C. R. Rizza, D. S. Anson, D. J. G. Rees, N. Ferrari, and G. G. Brownlee. 1984. Characterisation of an intragenic polymorphic marker for detection of carriers of hemophilia B (factor IX deficiency). Lancet. i;239-241.

24. Rees, D. J. G., C. R. Rizza, and G. G. Brownlee. 1985. Haemophilia $B$ caused by a point mutation in a donor splice junction of the human factor IX gene. Nature (Lond.). 316:643-645.

25. Chance, P. F., K. A. Dyer, K. Kurachi, S. Yoshitake, H-H. Ropers, P. Wieacker, and S. M. Gartler. 1983. Regional localization of the human factor IX gene by molecular hybridization. Hum. Genet. 65:207-208.

26. Camerino, G., K. H. Grzeschik, M. Jaye, H. de la Salle, P. Tolstoshev, J.-P. Lecocq, R. Heilig, and J. L. Mandel. 1984. Regional localization on the human X-chromosome and polymorphism of the coagulation factor IX gene (haemophilia B locus). Proc. Natl. Acad. Sci. USA. 81:498-502.

27. Boyd, Y., V. J. Buckle, E. A. Munro, K. H. Choo, B. R. Migeon, and I. W. Craig. 1984. Assignment of the hemophilia B (factor IX) locus to the q26-qter region of the X-chromosome. Ann. Hum. Genet. 48:145152.

28. Mattei, M. G., M. A. Baeteman, R. Heilig, I. Oberle, K. Davies, J. L. Mandel, and J. F. Mattei. 1985. Localization by in-situ hybridization of the coagulation factor IX and of two polymorphic DNA probes with respect to the fragile-X site. Hum. Genet. 69:327-331. 
29. Jones, R. W., J. M. Old, R. J. Trent, J. B. Clegg, and D. J. Weatherall. 1981. Major rearrangement in the human $\beta$-globin gene cluster. Nature (Lond.). 291:39-44.

30. Bray, G. L., and A. R. Thompson. 1986. Partial factor IX protein in a pedigree with haemophilia B due to a partial gene deletion. J. Clin. Invest. 77:1194-1200.

31. Vanin, E. F., P. S. Henthorn, D. Kioussis, F. Grosveld, and O. Smithies. 1983. Unexpected relationship between four large deletions in the human $\beta$-globin gene cluster. Cell. 35:701-709.

32. Mager, D. L., P. S. Henthorn, and O. Smithies. 1985. A Chinese thalassemia deletion: comparison to other deletions in the human Bglobin gene cluster and sequence analysis of the break points. Nucl. Acids Res. 13:6559-6575.

33. Lehrman, M. A., D. W. Russell, J. L. Goldstein, and M. S. Brown. 1986. Exon-Alu recombination deletes $5 \mathrm{~kb}$ from the low density lipoprotein receptor gene producing a null phenotype in familial hypocholesterolemia. Proc. Natl. Acad. Sci. USA. 83:3679-3683.
34. Giannelli, F., and G. G. Brownlee. 1986. Cause of the inhibitor phenotype in the haemophilias. Nature (Lond.). 320:196.

35. Shapiro, S. S. 1984. Genetic predisposition to inhibitor formation. In Factor VIII Inhibitors. L. W. Hoyer, editor. Alan R. Liss Inc., New York. 45-55.

36. Gitschier, J., W. I. Wood, E. D. G. Tuddenham, M. A. Shuman, T. M. Goralka, E. Y. Chen, and R. M. Lawn. 1985. Detection and sequence of mutations in the factor VIII gene of haemophiliacs. Nature (Lond.). 315:427-430.

37. Antonarakis, S. E., P. G. Waber, S. O. Kittur, A. S. Patel, H. H. Kazazian, M. A. Mellis, R. B. Counts, G. Stamatoyannopolous, E. J. W. Bowie, D. N. Fass, D. D. Pittman, J. M. Wozney, and J. J. Toole. 1985. Haemophilia A: detection of molecular defects and of carriers by DNA analysis. $N$. Engl. J. Med. 313:842-848.

38. Phillips, D. G., S. Aronis, G. Tsiftis, and H. H. Kazazian. 1986. Detection of six new mutations in haemophilia A. Clin. Res. 34:654A. (Abstr.) 